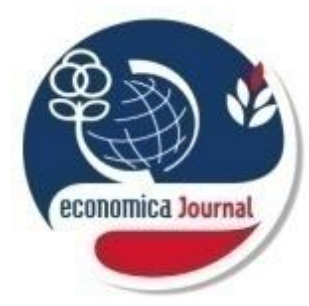

ISSN : $2302-1590$

E-ISSN: $2460-190 X$

\title{
ECONOMICA
}

\author{
Jurnal Program Studi Pendidikan Ekonomi \\ STKIP PGRI Sumatera Barat Vol.8 No.1 (20-27)
}

\section{DETERMINING PEDAGOGIC AND PROFESSIONAL COMPETENCIES AMONG STUDENTS IN REALIZING SOCIETY 5.0}

\author{
By \\ Bambang Ismanto ${ }^{1)}$, Sonia Laksita Erbianita ${ }^{2)}$ \\ ${ }^{1)}$ Economic Education Study Program Universitas Kristen Satya Wacana Salatiga \\ Email : bambang.ismanto@uksw.edu \\ ${ }^{1)}$ Economic Education Study Program Universitas Kristen Satya Wacana Salatiga \\ Email : sitalaksita@gmail.com \\ Submited: 2019.09.14 Reviewed: 2019.10.18 Accepted:2019.10.15 \\ https://doi.org/10.22202/economica.2019.v8.i1.3593
}

\begin{abstract}
The application of information technology is very useful in improving teaching skills and content development.. The magnitude and pace of information in society influences the variation, depth and complexity of education and learning studies. This paper's aim is to conduct a critical analysis of technological empowerment in the development of pedagogical and professional competencies as prospective professional teachers. The study was conducted with a qualitative approach among students in the economic education study program, FKIP, Satya Wacana Christian University, Salatiga, Indonesia. Data collection techniques are carried out by interviews, observation and focus group discussion. Sources of research data include students, administrators of student associations, and lecturers. The research found that students have applied information technology for college administration, found learning resources, published lectures, business and social media.that the students had applied information technology to lecture administration, found learning resources, published lectures, business and social media. Artificial intelligence is formed by looking for content, opportunities, and self-development networks. More specifically, students explain that unlimited access provides easy learning about how to teach (pedagogically) and deepen the theory of the economy (professional). The path of academic and social communication develops on line and reaches out to objects that are relevant to their studies. Meanwhile, the lecturers recommend that students need to be facilitated by broad access, to facilitate students in information technology applications.
\end{abstract}

Jel Classification:

A29; $A 2 ; B 14 ; A 2$

Keywords: Society 5.0, Artificial Intelligence, Social and Professional Competence

C2019 Prodi Pendidikan Ekonomi STKIP PGRI, Padang 


\section{INTRODUCTION}

The society cannot be separated from the process of development and application of information technology. The 4.0 industrial revolution is characterized by a cyberphysical system. The industrial world began to touch the virtual world, in the form of human, machine and data connectivity, everything was everywhere. This term is known as the internet of things (IoT). Education in the 21st century provides opportunities for students to obtain information with big data, fast, systematic and efficient. In order for students to access data systematically, skills in technology, media and information are needed. Prospective professional teachers will prepare early in mastering the skills of accessing information technology. As agents of learning, teachers will motivate, convince and direct the future of their students. This learning content will complement prospective teachers in professional assignments. The 21st Century skills which are considered to strengthen social capital and intellectual capital, commonly abbreviated as $4 \mathrm{C}$ : communication, collaboration, critical thinking and creativity.

The view that universities are factories that produce graduates focusing exclusively on STEM (Science, Technology, Engineering and Math) is a narrow and erroneous view. Higher education must make people more dignified. Universities also need to review whether what they have done so far is correct and is in accordance with the nature of the existence of the higher education institution itself (Majelis: 2016). The industrial revolution 4.0, is a real change in life that is getting smarter in the process of human life. Work efficiency and effectiveness are loyal targets wave of the industrial revolution, Reduction of human labor with machines is the era of industry 1.0. In the next stage, the era of industry 2.0 focused on large-scale production with quality standards. Meanwhile, Industry 3.0, developed a product that is increasingly flexible by applying robots in manufacturing. The era of the 2000s to the present is the era of the application of modern technology, including fiber technology and integrated network systems, which work in every economic activity, from production to consumption (Yahya:2018). Furthermore, Yahya identified the industrial conception 4 of the thoughts of the technocrats. Flexible mass production technology has been introduced by industry 4.0. The machine will operate independently or coordinate by humans. Ismanto (2019),said that industry 4.0 is an approach to control the production process by synchronizing time which has been carrying out unification and adjusting production. Many changes has been brought in human life by industry 4.0. Industry 4.0 has fundamentally changed and given a big influence on the way people move and the world of work. The form of effectiveness and efficiency of resources and production costs are the positive influences of industy 4.0 even though it also has an impact on reducing employment.

The implications industry 4.0 on education, integrating phenomena in digital literacy. Cyber technology, has a great ability to collect data, automatic identification, decision making that is right and credible. Innovation and application of information technology into learning becomes dynamic and creative. Data support and processing are very supportive of systematic information needs in improving the quality of output. They have digital literacy skills, technology, and human literacy that are relevant to solving the problems they face. (Halili: 2019: 1). This means that education 4.0 will be more efficient, effective, productive and 
creative in improving the quality of human resources.

Implications of Industrial Revolution 4, every human being through education must be able to function well in the human environment. The attitudes and skills developed include: Humanities, Communication \& Design. Universities need to look for methods to develop student cognitive capacity: higher order mental skills, critical \& systemic thinking: very important to survive in the era of industrial revolution 4.0 (Ahmad: 2018). Furthermore, Ahmad, recommends education programs at relevant universities include: 1 . Skills, including leadership (leadership) and working in a team (team work) 2. Agility and cultural maturity (Cultural Agility): Students with various backgrounds are able to work in different environments (inside / outside the country). 3. Entrepreneurship (including social entrepreneurship). The lecturer's content development includes thematic studies of various disciplines, connecting with the real world, project based-learning.

Cyber applications are used in communication, social media, buying and selling goods and services and ordering transportation. Business is getting easier and more practical to bring together interested parties. Activities and virtual domains are empowered by start-ups in various creative businesses. Millennials creatively create content on Yuotube and Instagram that gives quite promising results. In education, the application of cyber technology has become a facility for developing virtual learning. The developers design creative learning that makes it easy for customers to improve and evaluate. Users are facilitated since registration, the learning process and online evaluation.
Society in Japan in the era of Society 5.0 collaborates and integrates different systems to create new values. In this activity it is planned to standardize data formats, models, system architectures and more advanced applications. Human resource development through enhancing intellectual property, international standardization, construction of IoT systems, big data analysis technology, and artificial intelligence. This thinking in the framework of increasing Japan's competitiveness as a "super smart society" (Ferreira,: 2018: 27). Meanwhile, Fukuyama (2018) explains that the goal of Community 5.0 is to create a human-centered society. Economic development and solutions (solutions) to the challenges of society can be realized, and everyone can enjoy a high quality of life, personal and comfortable. This condition is a society in the future where everyone's various needs are met, without being limited by region, age, gender, language, culture and politics. Various goods and services are fulfilled and can be enjoyed by anyone and anywhere. The indicator of its success is the combination of cyber space and the real world (physical space) to produce quality data, and can produce new values and solutions to solve the challenges of people's lives. The national vision put forward by Japanese society is a new society-centered society and the ability to solve social problems quickly and provide comfort to everyone.The development of information technology will affect student's behavior. Conventional relationships are shifted into social networks based on digital communication. According to Ferreira (2018:26), society 5.0 is an extremely recent concept as a guide for social development and that can have a profound impact on societies at all levels, such as in terms of the quality of life and sustainability.

The development of information technology will affect student behavior. Conventional relationships are transferred to 
social networks based on digital communication. According to Ferreira (2018: 26), community 5.0 is a new life order concept as a framework for community development and has a profound impact on various social strata, including quality of life and sustainability.

Society 5.0 can be interpreted as a concept of a society that is centered on humans and is technology based. Artificial intelligence that pays attention to the human side will change a large amount of data collected through the internet in all areas of life. The community will establish meaningful social policies in the new order in society. This transformation will help humans to live more meaningfully. In Community 5.0, the need to balance economic achievement with the resolution of social problems is emphasized.

As candidates for professional teachers, Economics Education students are required to master personal, social, pedagogical and professional competencies. Satya Wacana Christian University prepares internet facilities with $1 \mathrm{~GB}$ of bandwidth allocated for the WIFI network: $800 \mathrm{MB}$ and around $200 \mathrm{MB}$ internet network. Campus internet and intranet networks, facilitate learning, electronic books, access to scientific journals, assignment reports, and academic administration. Besides that, this

\section{METHODS}

This research was conducted with a qualitative descriptive approach, with students' research subjects from the Educational Study Program, Satya Wacana Christian University. Data collection is done by technical observation, interviews and Focus Group Discussions. This research focuses on the use of information technology and the formation of intellectual artificial pedagogical and professional competencies. Personal and social competences are developing in an informal environment with network is also used for recreation, games, online business and social media. The industrial revolution 4.0 creates dependency in the activity of obtaining large data for meeting information's need and developing competencies.

Pedagogic and professional competencies are developed with electronic based data in the development of soft and hard skills. While the development of personal and social competencies, developed in an informal environment. Dependence on technology with a relatively large time allocation has the effect of decreasing social interrelation. Intellectual ability is built in electronic networks between lectures, research, business and social media. Relationship between humans in a pseudo atmosphere since the relationship and transformation are made in information technology networks. Research on the development of pedagogic and professional competencies in artificial intellectuals as the implications of the application of information technology has become important in the learning of economic education students. This study analyzes critically about technological empowerment in the development of pedagogical and professional competencies as prospective professional teachers.

internet access that is not limited in type and size. Meanwhile, research sources are students, lecturers and Chair of the Study Program. To increase data trust, triangulation is done by adding information sources, and extending the time of research. Data analysis was carried out by stages of data collection, reduction, presentation of data and conclusions.

\section{RESULTS AND DISCUSSION}

The Observations in the learning environment both classrooms, libraries, 
discussion rooms, cooperative laboratories, foreign language conversations and rest rooms, students were not separated from hand phones and computers connected to the internet. Economic education students in providing explanations, answering questions and solving problems raised by their lecturers utilize the internet network. Some students engaged in discussions about how to find complete learning resources, easy to access, and free of access costs. The students showed joy when getting accurate information according to the assignments of their lecturers. In a conversation observed, some students corrected the information discussed in class. Meanwhile, the lecturers concerned motivated and showed several economic and pedagogical scientific journals. The evolution of digital and cyber technology is the implication of Industry 4.0. This dynamic of life is a digital revolution because of the proliferation of computers that have the ability to read and store very large data. Industry 4.0 covers the era of technological disruption due to connectivity and automation in the field of activities. This has an impact, the industry is getting ahead and developing but in a non-linear competition. One form in the application of industry 4.0 is the application of artificial intelligence that disrupts the workforce. The use of robots can reduce operational costs, and increase efficiency and effectiveness. In education, Halili (2019: 6) explains that industry 4.0, each student can actualize potential creatively. Through internet, millions of information are provided to support the development of knowledge and skills. Through the internet, facilities are provided to interact and collaborate openly without space and time restrictions.

Interviews with students about the function of connections in information technology applications stated that

"the development of information technology with big data, helps students find, develop knowledge and store data. Access that is not limited to time, place, type, volume and quality encourages oneself to develop optimally. Added, the learning process becomes smart to actualize themselves according to their potential ".

Interviews around utilizing internet access, they stated that

"Interconnection networks are used to register lectures, get books, access journals, answer assignments, examinations, and social media and even business online. Internet network facilities on campus, support learning, selfdevelopment, character, business and friendship communication. Flexible learning, which developed campus, making it easier for students to access lecture plans, materials, formative tests and examinations. "

Digitization of data processing, suggests simple, smart and systematic learning. Students and lecturers must be able to plan learning that focuses on improving pedagogical and professional competencies. Therefore, in time our graduates become teachers, later technology will develop more dynamically at a fast, efficient and expanding network. Hariharasu (2018: 6), states that digital technology is developing rapidly and is able to manage millions of information. Students need training assistance so they have the competence to operate various digital technology instruments. Independently students can find information with many choices. They don't have to start with the same. Depending on their interests and needs, students will find sources of information, choose, classify, and establish meaningful information in their lives. Teachers need to assist in improving the skills for students to empower digital technology as a learning facility. The implication of the 
industrial revolution 4.0 is education 4.0 which empowers digital technology in problem solving, intellectual enhancement, and life skills. Students will prepare themselves for the next stage of the industrial revolution.In the focus of group discussions followed by students attended by lecturers and Chair of the Study Program, it was concluded that

"(1) the Industrial Revolution 4.0 was a digital revolution, which was marked by the proliferation of computers and the automation of recording, change and storage (2). Transformation of information, decrease in operational costs (3) Big data in lectures as an opportunity to read, analyze and optimize utilization for programing, coding, web development, and other skills"

Education 4.0 as a response and implication of the 4.0 industrial revolution that harmonizes people and technology in new life with great opportunities. Learning is developed with a vision of encouraging students to identify resources to increase knowledge and skills (Hussin: 2018: 92). This means that technology as an instrument facilitates students to process various information relevant to the knowledge and skills they develop. Special interviews with lecturers stated that :

"The industrial revolution 4.0 influences the social and cultural behavior of students. The physical contacts of lecturers and students are diminishing, due to faster internet communication, and smart. Academic administration systems, guardianship, guidance, developed based on line students can access from various places and times according to their choice. The lecturers are worried, the character of students experience problems in the formation of personal and social competencies, while for pedagogical and professional competencies there is no problem."

Vamn, John \& Cedric, stated that the application of the latest technology could increase the effectiveness of the teaching and learning process. Students will be more interested, attentive and enthusiastic about learning that applies new technology (Halili: 2019: 6). Thus, education 4.0 will further improve the quality of learning. Student creativity can be developed with a variety of learning innovations and technology support. Observation of micro teaching activities in the laboratory in developing pedagodic competencies, showing :

(1) High skills in media use, and online learning (2) effective communication skills, (3) motivating abilities (4) Operation of digital media (5) ability to manage classes, (6) ability to conduct valid and reliable evaluations, and (7) remedial learning and enrichment.

In terms of social change, in the FGD, "it was concluded that the era of Society 5.0, artificial intelligence would transform big data in all walks of life and the Internet of Things would become a new wisdom, which would be dedicated to enhance human capabilities to open opportunities for humanity. This transformation will help humans to live more meaningful life". According to Ferreira's thought (2018: 28), the target of 5.0 people is to improve the quality of life of the people. Productive and technological potential of Industry 4.0 will revitalize and empower productive potential for the benefit of society. As a final goal and, to some extent, an unavoidable goal, Society 5.0, will revolutionize society by improving our way to exist and live in the community, both our personal and professional lives.

Access to information technology provides big data, free of place and time and is affordable. A summary of interviews with several students stated that 
"Internet access for reading books, doing assignments, games, online business and social media takes relatively high time. They get the knowledge, skills, recreation and information that are important in their lives. Psychologically, intellectuals improve with various information that is important for their lives. We are aware that this electronic-based activity will reduce the ability to interact socially. Meanwhile, the lecturers when confirmed on this statement, argued that access to electronic communication was important, but we also need to develop human relationships. This thought is conveyed by considering that the school environment, teacher functions are still relatively dominant in the pace of information technology development. Improvement of access facilities needs to be done by the University to be more efficient in finding information according to student needs. Thus, students have sufficient time to interact socially with others and lecturers".

Society 5.0 will solve and prepare solutions to reduce the negative impact of the industrial revolution 4.0. However, this era of life will require the opening of 'five walls' barriers, i.e. ministries and institutions, the legal system, technology, human resources, and social response. This condition will be a global challenge from the government, industrial environment and academics expected to be a role major in innovation and ecosystem creation (Fukuyama: 2018: 50). In developing competencies, the application of information technology is a facility and the instrument will not be able to replace the social function of humanity. Intellectual development in electronic learning is formed quickly, widely and is validly recorded. This artificial intellectual will reduce social response based on human values. As a professional teacher places the application of technology as a facility in the formation of soft and hard skills.

\section{CONCLUSSION}

This study concludes that (1) Application of information technology in industrial revolution 4.0 supports the development of pedagogic competencies in terms of learning about teaching and professional competencies about economic theory (2) Unlimited access makes it easy to read electronic books, scientific journals, evaluations, online businesses, and social media (3) Various information increases knowledge and skills in artificial intellectuals. Based on this conclusion it is recommended (1) Campus management improves public space as social interaction (2) Learning design gives students the opportunity to pay attention to one another (3) Realization in social 5.0, formed in curriculum development

\section{REFERENCE}

Ahmad, Intan, (2018), Proses pembelajaran digital dalam era revolusi industri 4.0. Direktur Jenderal Pembelajaran dan Kemahasiswaan, Kementerian Riset, Teknologi, dan Pendidikan Tinggi, Medan, 17 Januari 2018

Ferreira, Carlos Miguel \& Sandro Serpa , 2018, Society 5.0 and Social Development: Contributions to a Discussion, http://mos.sciedupress.com Management and Organizational Studies Vol. 5, No. 4; 2018

Fukuyama, Mayumi,2018, Society 5.0: Aiming for a New Human-Centered Society, https://www.jef.or.jp/journal/ Japan SPOTLIGHT • July / August 2018

Halili, Siti Hajar, 2019, Technological Advancements In Education 4.0The 
Online Journal of Distance Education and e-Learning, January 2019 Volume 7 , Issue 1

Hussin, Anealka Aziz, 2018, Education 4.0 Made Simple: Ideas For Teaching, International Journal of Education \& Literacy Studies ISSN: 2202-9478, www.ijels.aiac.org.au

Ismanto, Bambang, 2019, Implikasi Program Pendidikan Guru Dalam Revolusi Industri 4, Disajikan Pada Talkshow Menyiasati Revolusi Industri 4.0 dalam Konteks Pendidikan, UKSW, 10 Januari 2019

Majelis Pendidikan Dewan Pendidikan Tinggi Kementerian Riset, Teknologi dan Pendidikan Tinggi, Memandang Revolusi Industri \& Dialog Pendidikan Karakter Perguruan Tinggi di Indonesia, 2016, Direktorat Pembelajaran Direktorat Jenderal Pembelajaran dan Kemahasiswaan Kementerian Riset, Teknologi, dan Pendidikan Tinggi

Yahya, Muhammad, (2018), Era Industri 4.0: Tantangan Dan Peluang Perkembangan Pendidikan Kejuruan Indonesia, Pidato Pengukuhan Penerimaan Jabatan Professor Tetap dalam Bidang Ilmu Pendidikan Kejuruan Fakultas Teknik Universitas Negeri Makassar, 14 Maret 2018 